\title{
CUSTOMER RELATIONSHIP MANAGEMENT IN BUSINESS-TO-BUSINESS MARKETING: EXAMPLE OF TOURISM SECTOR
}

\author{
Demet TUZUNKAN* \\ Woosong University - SIHOM Department, 171 Dongdaejeon-ro, \\ Dong-gu, 34606 Daejeon, SouthKorea, e-mail: demettuzunkan@gmail.com
}

\begin{abstract}
Citation: Tuzunkan D. (2018). CUSTOMER RELATIONSHIP MANAGEMENT IN BUSINESSTO-BUSINESS MARKETING: EXAMPLE OF TOURISM SECTOR. GeoJournal of Tourism and Geosites, 22(2), 329-338. https://doi.org/10.30892/gtg.22204-291
\end{abstract}

\begin{abstract}
Abtract: The aim of this study is to demonstrate how customer relationship management systems are implemented in tourism companies that do business-tobusiness marketing. The study firstly tries to explain the concepts of business-tobusiness marketing and customer relations management. The existence and implementation of customer relationship management systems, particularly in business-oriented organizations, is crucial in order to make a difference in the globalizing world where competition conditions are gradually increasing. In order to achieve this, it has been evaluated how the customer relationship management systems are formed, how they are implemented, and what advantages they provide by conducting interviews with the employees in the companies that are business-tobusiness marketing in tourism sector and business areas. In methodology, semistructured interview technique has been used which enables qualitative data collection as a method in order to reach the goal of the study. As a result of the interviews and research, it has been established that customer relations management in B2B tourism companies is quite vital to be more productive, work efficiently, support marketing activities considerably and therefore increase the sales volume.
\end{abstract}

Key Words: Business to Business Marketing, Customer Relationship Management, B2B, Tourism, CRM

\section{INTRODUCTION}

The technological advancements in the globalizing world and the rapid change in socio-economic conditions result in the increase of customer's demands and expectations. The high variety of services and products in the market challenges the customers to make a choice and forces them to question their loyalty. Businesses are well aware that they have to adapt to the requirements of the modern age in order to be able to compete and preserve their presence in the market. In this vein, they take important customer-related steps both to win the customers and ensure their loyalty. Customer relationship management has

\footnotetext{
* Corresponding author
} 
become an approach that arises precisely as a result of these considerations. The concept of customer relationship management has become a very important system for companies that are doing business-to-business marketing (B2B) as well as for companies that are doing business-to-consumer marketing (B2C). Therefore, it is very important for the customers to establish customer management systems and use them effectively and regularly in order to reach the customers correctly and effectively. In particular for service business, managing customer relationship is important because of the inherent intangibility and heterogeneous characteristics associated with service delivery (Singh, 2017, 49). Vogt (2011, 361-362) states that, in order to be more effective in CRM in tourism industry; there should be partnerings with destination marketing agencies, engaging with industry partners such as travel companies, following technology and business innovations and adoption patterns to be ahead of the curve on what society is eager to have and how innovative firms are piquing consumer's curiosities, becoming involved in other disciplines or venues that are developing and researching CRM and invitings CRM consultants and firms and organizations practicing CRM to travel and tourism research conferences. B2B enterprises have started to establish and implement customer management systems that are formed according to total quality management standards in order to be able to record information about purchasing behaviors related to customers, to make customer segmentation and to communicate with them in this direction and to make them feel valuable. Thus, they aim to achieve customer satisfaction and loyalty and to be successful in long term brand image and sales volume.

\section{BUSINESS-TO-BUSINESS (B2B) MARKETING}

Business-to-business marketing is defined as "the marketing of goods and services to commercial enterprises, governments and other non-profit organizations for use in goods and services they produce to sell to other industrial customers" (Chaston, 1999). The American Marketing Association Board of Directors defines marketing as set of activities of institutions, and processes for creating, communicating, delivering, and exchanging offerings that have value for customers, clients, partners, and society at large (www.ama.org). Business-to-business marketing, on the other hand, is sometimes called commercial marketing or industrial marketing (Miller and Washington, 2016). As an academic effort starting at the beginning of the 1900s, marketing has been present for 100 years, while business-to-business marketing has been present for over 30 years. Although it has not been given enough publicity in marketing research, there have been important developments in the meantime and it claimed a rich place in the literature (Chaston, 1999). The theory of business-to-business marketing completes its development in these three stages in line with development phases: pre-industrial, industrial, and postindustrial stages. According to Polonsky et al. (2010), the pre-industrial era is divided into two as the potential relationship stage between the buyer and the seller and the relationship discovery stage. During the potential relationship phase, the parties begin to acknowledge each other or to confirm the existence of a potential business partner. They are not in communication yet. In the relationship discovery phase, there is no communication yet, but they evaluate each other's ability to develop relationships. In the industrial era, the buyer or seller communicates directly or indirectly with the other. This leads to a negotiation process that assesses whether the actors have decided to start developing a relationship with the other. In other words, this process is a search and trial process that creates a common ground between the parties. In the post-industrial era the parties communicate with other buyers or sellers in order to better understand the character of the potential business partner. As both partners are committed to more, they are more eager in terms of their relationship in taking greater risk, such as sharing more confidential information in order to be successful (Baxter, 2013, p.14). 
The large investments in business-to-business marketing in the past usually focused on logistics, sales force management, and after-sales support (Weitz \& Wensley, 2002, 463). The first marketing theory was based on the direct application of economic theory. In industrial purchases the fundamental criterion was an acceptable quality and a reasonable price. Parties in trade preferred the lowest-cost supplier. Although the economic theory at stake could not fully predict or give an account of business-tobusiness purchasing decisions, it at least created an academic curiosity in order to try to understand how and why exceptions grow even more in making a "rational" decision (Hadjikhani \& LaPlaca, 2013). The importance of business-to-business marketing, which was known as the industrial marketing, could be established by considering that for each customer market, there are several higher enterprises where the product or service should be first processed in the leading markets of each other, before it is consumed finally. The scope of the most business-to-business marketing activities is the trade between the supplying and purchasing enterprises, widely known as "the supply chain." This metaphorical concept connects the market (s), the distribution network, the production process, and the procurement (or procurement) activities carried out on behalf of suppliers and other stakeholders, and can occur between different types of businesses.

Business-to-business marketing is a vast and important field of marketing practice and theory (Ellis et al., 2011). Although the market among the enterprises is bigger, it is also dependent to a great extent on the customer markets. The reason for this dependency is the fact that the most of the demand for customer goods is the source for the enterprises' demand for goods (Haley, 2012). Among the characteristics which separate B2B from B2C, there are (Blythe, 2006, 28);

1. That more than one person is involved in the purchase

2. That there are professional purchasers

3. That there are fewer purchasers in most markets

4. That the size of the orders is large

5. That the purchasing processes occur in a more formal, more professional framework.

The difference between $\mathrm{B} 2 \mathrm{~B}$ and $\mathrm{B} 2 \mathrm{C}$ is important not only in terms of positioning, strategy and communication but also as a criterion used in the classification of industry goods (Pötter, 2009, 6). As it can be seen, business-tobusiness marketing is one of the widest, most developing and most attractive areas of marketing. The experts comment that it has many aspects open to exploration even after so much detail. This marketing type active in production and trade in our country, has, and will continue to have a presence in the supply of national and international brands, sub-industry, transportation, logistics, and many more areas. It is obvious that the business-to-business marketing, which has different dynamics from the customer oriented marketing, has great importance for marketing. However one may say that there are some deficiencies in terms of relationships with customers especially in our country. In this context, to understand the operation to be cooperated, it is crucial to ask the right question, to understand the customer in the best way and act accordingly .

\section{CUSTOMER RELATIONSHIP MANAGEMENT}

Customer relationship is all activities designed to initiate, preserve and develop a long-term bond (Govoni, 2004, 54). In the current sense, customer relations is a broad process involving all the pre-sales and after-sales activities between the business and the customer in order to continue a steady relationship with their customers, and to have more information related to the needs and the behavior of the customers in this regard (Beksirgakızı, 2007, 2). Customer relationships management (CRM) is a management philosophy arising in close connection with the union of marketing and information 
technology (Gardial, 2004, 121). When we take a look at the literature, we see that there are many definitions related to customer relationship management. This suggests that it is a concept difficult to define. The difficulty in defining it is partly explained by the fact that this management approach targets different customers and appeals both to the customer market and the enterprise market. In this context, it can be said that the concept in the basic meaning of the customer relationship management is a philosophy, process, and management of the customer relationship development (Demir \& Kirdar, 2007, 296). Customer relationship management helps the enterprises define and classify their target customers. Thanks to the data uploaded on to the database, customers will be better known for the next sale, and be approached with suitable strategies after being classified in terms of purchasing behavior. However, in a sector such as banking where the competition is very high, customer profiles can be built by monitoring the transactions done by the customers, after the customer data is evaluated on its own or as a whole, following the more efficient use of information processing systems. Market segmentation could be done more efficiently. That is why enterprises and institutions should save all the customer information and the characteristics analyzed based on this information in their databases, and should conduct research work on their data warehouse. It means that important investment should be made in customer relationship management. For customer relationship management it is vital that efficient information processing and fast and continuous service should be provided to the customer (Taskin, 2009, 62-63). Today's high competition makes it necessary that enterprises B2B marketing should be re-structured, and revise their strategies and approach to the customers. The commercial customer who is an element of higher competition is continuously stimulated and forced to consume in high speed communication technology. These enterprises, which are aware that there are many alternatives in the present situation, will naturally tend to develop relationships with enterprises which value them and which they trust. This is a risk factor for all businesses. However, this awareness also makes it harder to win commercial customers.

The biggest difference between $\mathrm{B} 2 \mathrm{~B}$ marketing and other marketing customer relationship management applications, is that the business transcend sales and marketing departments and comes to include other functional areas such as human resources, risk management and customer management in total quality management. It cannot be conceptualized on its own; rather necessary plans are made taking all the departments as a whole. Here the main goal is to strategically develop long term relationships which will benefit both enterprises and commercial customers (Beksirgakizi, 2007, 4).

\section{METHODOLOGY}

The purpose of this study is to demonstrate how customer relationship management systems are implemented in tourism companies whose target market is tourism enterprises. To this end, answers to the following questions were sought:

1. Do you have customer relationship management (CRM) system implemented and efficiently used?

2. Based on what was your CRM system implemented in your tourism enterprise formed?

3. What activities does the CRM system implemented in your tourism enterprise include?

4. Is there a department or a person responsible for tourism CRM activities in your enterprise?

5. Are you personally involved in some of these activities? Could you explain your duty if you are involved in these activities?

6. In an enterprise such as yours which engages in business-to-business marketing activity and what advantages would implement in active use of a CRM system?

7. Are there any suggestions you would like to make to develop the CRM system for your enterprise? 
In this study, semi-structured interview technique has been used which enables qualitative data collection as a method in order to reach the goal of the study. The real aim of the interview technique is, apart from proving a hypothesis, to try to understand the related people's experiences and how they relate to these experiences in terms of the subject. The semi-structured interview is a technique which consists of providing the related people a flexible but standard interview form. Researchers prefer using semistructured interviews because questions can be prepared ahead of time. This allows the interviewer to be prepared and appear competent during the interview (Cohen, 2006). Accordingly, with the semi-structured interview technique used in this study, it has been aimed to get meaningful, qualitative data in line with the responses given. In this study which was conducted with tourism enterprises in general between September 2017-January 2018, the research group consists of 12 people working in tourism, travel agency, food and hospitality sectors and somehow engaging in customer relationship management activities in Istanbul province. The interlocutors were contacted face-to-face, via telephone or e-mail, and they were asked to share their experiences related to the subject and relay information.

\section{FINDINGS AND EVALUATION}

This section will be devoted to the findings accumulated upon the analysis of the qualitative data collected by interviews with people who engage in CRM activities and are knowledgeable about the CRM activities in their enterprises. The names of the participants will be kept confidential, and they will be referred to as $\mathrm{P}_{1}, \mathrm{P}_{2}, \mathrm{P}_{3}$ etc. The findings of the study, based on the interview questions, are considered to be a subject, and presented with sub-headings formed in line with the responses of the study participants. The participants have been asked questions such as if there are CRM activities in their business, how it has been implemented if there is any, whether they personally engage in these activities, what advantages the CRM system brings, and the information acquired will be explained one by one, accompanied with examples when necessary.

Research Findings on Participants' Socio-Demographic Characteristics

The participants in the study, $67 \%$ were female while $33 \%$ were male. We can see that $8 \%$ of the participants are aged $18-24,25 \%$ is aged 35 or older, and $67 \%$ is aged $25^{-}$ 34 . As seen above, $42 \%$ of the participants have a masters degree while $58 \%$ have a bachelor degree. According to the information above, $17 \%$ of the participants are senior manager or executive director, $25 \%$ are c-level executive or authority and $58 \%$ are intermediate manager or specialist.

Findings about the existence of customer relationship management system in the enterprises the participants work at:

All participants confirmed that they have a customer relationship management system at their enterprises. This situation shows that the need for and the popularity of customer management systems have been gradually increasing. Some of the participants stated that they have a similar customer management system, if not exactly a customer relationship management system, while others state that they had not had such a system until recently and they have just implemented such a customer system, that it is an ongoing process but the employees have been given training to facilitate their conformity. Some of the views of some participants on this subject are as following:

"We have a CRM software used for reporting and data storage if not exactly a customer relations management system." (P6)

"We have a newly implemented CRM software at our enterprise. Training has been given to the employees for the transition. It helps us conform to the new system to start using it in terms of learning and trying it out." (P10)

Findings about the formation of customer relationship management system in the enterprises the participants work at: 
Table 1. Findings about the formation of customer relationship management system in the enterprises the participants work at

Interview Questions

Based on what was your CRM system implemented in your tourism enterprise formed?

To meet customer expectations and for satisfaction

For easy tracking the internal company information

Because the current quality required a management system

As seen in Table 1, the question of "Based on what your CRM system was formed" was responded by 6 of the participants with the same answer as to meet customer expectations and for satisfaction. In addition, they mentioned the need to form such a system in line with the complaints, to meet the demand and give priority to production. Here is a related example on this subject: "It is a software formed with risk management orientation in order to give priority to the production in accordance with the wishes of the customers, to decrease the work load of the sales team, to track orders and delivery of the orders, and to provide sales and production reports more easily" (P10).

"It was formed in accordance with the feedback to customer complaints." (P9).

Three of the participants shared the information that the CRM system was formed as a response to the need to share internal company information. And some of the participants emphasized that the system was formed to facilitate the relay of information to their employees in the field. An example is shown below: "It was formed taking into account the tracking/controlling needs of the employees working in the field. Thus the information flow with the company is carried out more easily and our team in the field could work more efficiently and more productively. (K6)."

Three of the rest of the participants shared the information that the CRM system was formed as a necessity of the inter-company quality management processes and in accordance with the related standards. The implementation and effective use of CRM systems with ISO standards by companies which emphasize total quality management activities is quite important for the company quality, vision and success. Some of the views regarding this subject are as follows: "It was formed based on ISO 9001, ISO 9004, TS7246, ISO 10002 standards and customer experience internal procedure and processes" (P8).

"It was formed based on ISO TR 9001: 2015 Quality Management System" (P4).

"The CRM system at our company was designed in accordance with the quality management system stipulated in Quality Management System TS EN 9100:2016, TS EN ISO 9001:2015. The facilitation and development of the points below are shown as the grounds to meet the demands of both current customers and of potential customers (...)" ( P5) $_{5}$.

Findings about the activities involved by the customer relationship management system in the enterprises the participants work at:

Table 2. Findings about the activities involved by the customer relationship management system in the enterprises the participants work at

Interview Questions

What activities does the CRM system implemented in your tourism enterprise include?

Customer information, pre-sales and after sales tracking, prices etc.

Reporting

Sectoral tracking, evaluation of the market Total

As seen in Table 2, the participants shared their views on the activities involved by the customer relationship management system in the enterprises the participants work at. 
7 of the participants stated that they use the CRM system for the storage of customer information, pre-sales and after sales tracking, preparing price offers, while 4 of the participants said they use it for data analysis and reporting; and one participant maintained that it is used to evaluate the market in light of present data and following the sector closely in this regard. Some of the examples of the responses are as following:

"For recording customer contact details, sales tracking activities, and customer visit notes, for preparing offers, internal company assignments and tracking" (P2).

"For data storage and reporting" (P6).

"It includes the activities of stock tracking, production and production planning, marketing, accounting, cost calculation, sales marketing, OEM and reporting." (P10)

Findings about the existence of a person or a department responsible for CRM activities in the enterprises the participants work at:

Table 3. Findings about the existence of a person or a department responsible for CRM activities in the enterprises the participants work at

Interview Questions

\begin{tabular}{lc}
\hline \hline Is there a department or a person responsible for tourism CRM activities in your enterprise? & $\mathrm{f}$ \\
Yes & 10 \\
No & 2 \\
\hline Total & 12 \\
\hline \hline
\end{tabular}

As seen in Table 3, to the question of if there is a person or department responsible for CRM activities carried out at the enterprises they work at, 10 of the participants responded in the affirmative, whereas 2 of the participants responded in the negative. There were different responses from those who responded in the affirmative according to the company scale and institutional structure. It has been observed that in big scale companies there is usually a functioning customer relationship department, and many authorities are responsible for these activities while in medium scale and small scale companies, only one or a few people were specifically assigned to this duty. Some examples are as the following:

"Yes. Responsibility areas were established and assignments were made in accordance with the Quality Management System. They are tracked regularly and reported to the management monthly" (P8).

"SAP ERP Management itself is responsible for the CRM activities" (P1).

"Everybody is charged with updating the system but there is one authority responsible for the software and use" (P2).

Negative respondents generally reported that all employees were involved in CRM activities but that no person or department was specifically assigned to them. An answer to this is as follows: "The system is used by all departments (Accessories, Planning, Pricing and Loading) but not a single person is assigned to it" ( $\left.\mathrm{P}_{3}\right)$.

"We work as a team of one agricultural engineer, one milk technician and three food engineers. We are all responsible for CRM activities. However, no single department or person is assigned to it" ( $\left.\mathrm{P}_{3}\right)$.

Findings about the activities involved by the participants in the CRM activities:

Table 4. Findings about the activities involved by the participants in the CRM activities where the participants work at

\begin{tabular}{lc} 
Interview Questions & $\mathrm{f}$ \\
\hline \hline Are you personally involved in some of these activities? Could & \\
you explain your duty if you are involved in these activities? & \\
Yes & 9 \\
No & 3 \\
\hline Total & 12 \\
\hline \hline
\end{tabular}


As seen in Table 4, 9 of the participants stated that they are present at their companies as the solely responsible authority or partially responsible authority for CRM activities. Some of the participants who stated that they carry out CMR activities as the solely responsible authority are in the position of customer relation agent or in a similar position, while others stated that they only support CRM activities related to some departments (for example, sales transactions). And one user working at an institutionalized company said that all employees are responsible for CRM activities. Some examples from these interviews are as follow:

"I work directly as the responsible authority, I am the customer relations agent" (P9).

"I take part in the sales-marketing part of these activities. The quota-purchase activities with the customers, the product spectrum which must be prioritized in the region, market research about the dictates and niches of the market, establishing customer risk status and market research before production planning" (P10).

"All employees are responsible for customer relationship. They are all obliged to follow the established processes, with regard to the possible or actual problems, whether with internal or external customers" (P8).

The participants who said that they are not directly involved in or responsible for CRM activities stated their views as follows:

"It is not the case that I am actively involved. I only facilitate the changes necessary in accordance with the process" (P6).

\section{Findings about the advantages the participants think the CRM activities will bring to the institutions:}

Table 5. Findings about the advantages the participants think the CRM activities will bring to the institutions

Interview Questions

In an enterprise such as yours which engages in business-to-business marketing activity, what advantages would implementation and active use of a CRM system?

Marketing activities are supported

Tracking will be easier as all the information will be in one place

Relationships with the customers and the service provided can be measured

Customer satisfaction will increase

It allows planing production according to the demand

As it is seen in Table 5, the participants had various opinions on the advantages that can be gained in terms of the effective and regular use of CRM activities in an institution. While 4 of the participants are convinced that it is advantageous to collect all the data in a single system, 3 of them stated that CRM activities directly support marketing activities in allowing for sector research, analysis, pre sales, sales and after sales transactions, giving the scope of these activities. Moreover, addition of activities which will increase the satisfaction of internal customers is among the cited advantages. Examples of some views are summarized below: "The main advantages are that in B2B channels, especially sales teams follow activity, activity reporting, data sharing and cases, thus creating and following a common sales awareness and strategy; that the B2B channel is transformed into an active sharing platform by analyzing and reporting sales data, general and personnel-based measurement of sales effectiveness, performing category analyzes in SKU-based systems (in category management enterprises) and keeping the customer portal according to the level of integration of the system. With the collected data, sales management and sales support benefits such as visit reminders for sales management, frequency of visits, profit per visit, control of sales costs, can be obtained. 
Also, when we deal with the "sociological" side of B2B, there are special days, birthdays, etc. that are integrated into CRM systems modules can also provide support to sales teams for continuing personal warm relationships for connections" ( $\mathrm{P} 7)$.

"It brings advantages such as tracing the relationships with our customers, measuring the service we provide, observing "how can we be better?" offering equal quality service to all customers based on their needs, measuring fairness in terms of the compensations demanded for the service, determining deficiency in the service, and taking measurements and preventing these deficiencies" ( $\left.\mathrm{P}_{4}\right)$.

"It benefits the conduct of proper marketing activities. Because understanding the customer forms the base of the sales. Working with systems which meet the expectations adds value to the enterprise" (P11).

\section{The findings about the suggestions of the participants regarding the development of the CRM system at the institution they work for:}

Table 6. The findings about the suggestions of the participants regarding the development of the CRM system at the institution they work for

Interview Questions

\begin{tabular}{lc}
\hline \hline Are there any suggestions you would like to make to develop the CRM system for your enterprise? & \\
I do. It must be user-friendly & 1 \\
I do. It should be more marketing activities oriented. & 1 \\
Surveys can be conducted. & 1 \\
All employees should be integrated into the system and it should be used actively by everyone. & 2 \\
No, I don't & 7 \\
\hline Total & 12 \\
\hline \hline
\end{tabular}

As seen in Table 6, 7 of the participants which is a majority of them stated that they are happy with the present system they use and they do not have any suggestions. 2 of the participants stated that all employees of the company should be integrated into the system. Therefore the whole company can share information on a single system. 1 of the participants stated that the use of the CRM system should be easy and have no details, whereas 1 participant stated that the present CRM system is not marketing activities oriented, but it should be. 1 participant stated that survey system could be added to the CRM system, and therefore customer satisfaction could be measured easily. Examples of these views are given below: "It may be supported with online surveys but I think no different action is necessary" (P8).

"No, I don't. I am satisfied with the system we use ( $\left.\mathrm{P}_{5}\right)$.

"Surveys and brand analyses can be conducted and customer satisfaction could be thereby measured" (P9).

"The integration of different employees from each department of the enterprise might better the process" (P1).

\section{CONCLUSION}

The interviews as a research technique were conducted with people working at tourism companies that are business-to-business marketing to demonstrate the content, scope and advantages of the CRM activities regarding the present customer relationship management systems. The employees unanimously stated that they are aware of the advantages of CRM activities in terms of productivity, time management and profits, and emphasized the importance of CRM systems for a company, adding that they should be definitely implemented. Thus, it is clear how important CRM is for organizations with enterprises as their target market. It is vital to have a present customer management system approach at the tourism companies doing business-to-business marketing in 
order to preserve their place in the market, to ensure customer satisfaction and in the long term customer loyalty. In an atmosphere of high competition, the tourism companies are aware that the way to succeed is to put the customer on the focus. In this vein, success of the companies providing service to other businesses, which is a large market, is only possible by adopting, and effectively implementing a right customer relationship management policy suitable for the company. In this study interviews were conducted with 12 people working at enterprises in the tourism sector providing business-to-business service and they were asked to interpret their present CRM system at their companies. As a result, it has been established that each employee shares the view that the contribution of the CRM system to the company is undeniable, it takes them one step further in their present market, and it increases the internal company productivity. Moreover it has been stated that the system is developed in accordance with the necessities of the time, and it will need developments again. This suggests both that the companies design and implement this approach in line with the total quality management standards, and that the employees actually adopted the CRM system to a great extent and they are aware that it helps them in their efficient and productive work.

\section{REFERENCES}

Baxter R., \& Woodside A. (2013). Deep Knowledge of B2B Relationships Within and Across Borders. Emerald Group Publishing Limited, (1st Edition).

Beksırgakızı N. (2007). Customer relationship management in businesses and application in banking sektör, Unpublished PhD. Thesis, Marmara University.

Blythe J. (2006). Marketing. SAGE Publications Ltd, London.

Chaston I. (1999). Business-to-Business and Institutional Marketing, New marketing strategies: Evolving flexible processes to fit market circumstance, SAGE Publications, London.

Cohen D, \& Crabtree B. (2006). Qualitative Research Guidelines Project, (Online) http://www.qualres. org/HomeSemi-3629.html

Demir, O. F. \& ve Kurdar Y. (2007). Customer Relationship Management: CRM, Review of Social, Economic \& Business Studies, Vol.7/8, p. 293-308.

Ellis, N., Tadajewski, M. \& Pressey, A. (2011). Business-to-business marketin. SAGE Library in Marketing, (Vols. 1-4), SAGE Publications Ltd. (Eds.).

Gardial S. (2004). Customer Relationship Management (CRM), Encyclopedia of Health Care Management, SAGE Publications Ltd, Thousand Oaks, CA.

Govoni N. A. (2004). Customer Relationship Management, Dictionary of Marketing Communications, SAGE Publictions Ltd., Thousand Oaks, CA.

Hadjikhani A., \& LaPlaca P. (2013). Development of B2B Marketing Theory. Industrial Marketing Management (42), Elsevier.

Haley G. T. (2017). Marvel Encyclopedia of New Venture Management, SAGE Publications Ltd., Thousand Oaks.

Miller R. K., \& Washington K. D. (2016), Business-to-business Marketing 2016-2017 (2nd Edition), Richard K. Miller \& Associates, Loganville.

Polonsky, M., Gupta, S., Beldona, S. \& Hyman, M. R. (2010). Inactivity and the dynamics of relationship development: a proposed model, Journal of Strategic Marketing. 18 (3), p. 257-273.

Pötter A. (2009). Business-to-Business Markenführung im Web 2.0: Möglichkeiten der Einflussnahme und Maßnahmen zur Gegensteuerung, Diplomica Verlag, Hamburg.

Singh M. (2017). Customer Relationship Management in Travel \& Tourism Industry, IOSR Journal of Business and Management (IOSR-JBM), 19(6), p.47-53.

Taşkın E. (2009). Pazarlama Esasları, Türkmen Kitabevi, İstanbul.

Vogt C. A., (2011), Customer Relationship Management in Tourism: Management Needs and Research Applications, Journal of Travel Research 50(4), p. 356-364.

Weitz B. A. (2002). Wensley R., Handbook of Marketing, SAGE.

*** American Marketing Association (AMA), Definition of Marketing, (Online) https://www.ama.org/ AboutAMA/Pages/Definition-of-marketing.aspx 18.04.2017

Submitted:

20.10.2017
Revised:

23.04.2018
Accepted and published online

27.04.2018 